\title{
The Stage in Evidence: Foyer's Journal Study (1891)
}

\author{
Luciana Nascimento ${ }^{1}$, Joao Carlos de Souza Ribeiro ${ }^{2}$, Renata de Freitas Santos ${ }^{3}$ \\ ${ }^{1}$ Department of Literature Science, Faculty of Languages, Federal University of Rio de Janeiro, Rio de Janeiro, Brazil \\ ${ }^{2}$ Education, Languages and Arts Center, Federal University of Acre, Rio Branco, Brazil \\ ${ }^{3}$ Faculty of Languages, Federal University of Rio de Janeiro, Rio de Janeiro, Brazil
}

Email address:

zen.sansara@uol.com.br (L. Nascimento), joao.ribeiro@ufac.br (J. C. de S. Ribeiro), renatahdfs@ gmail.com (R. de F. Santos)

\section{To cite this article:}

Luciana Nascimento, Joao Carlos de Souza Ribeiro, Renata de Freitas Santos. The Stage in Evidence: Foyer's Journal Study (1891). International Journal of Literature and Arts. Vol. 9, No. 1, 2021, pp. 1-8. doi: 10.11648/j.ijla.20210901.11

Received: December 11, 2020; Accepted: December 28, 2020; Published: January 15, 2021

\begin{abstract}
The present work aims to rescue, in the course of history, the importance of Foyer's journal and its influence on the emerging cultural panel in Brazil. Despite its ephemeral passage on the national scene, since Rio de Janeiro was practically the stage for major political, economic, cultural and, above all, literary transformations, the aforementioned periodical played a relevant role in a society in formation, by the scenes of a city which intended to become a cultural pole in the tropics. This is a survey conducted in the collection of periodicals of the National Library Foundation/Brazil, together with a bibliographic research. We conducted a study of the chronicles published in the newspaper Foyer, highlighting the importance of theater in the new sociability that was formed in Rio de Janeiro in the 19th century. This work was part of the project "Urban cartographies: centers and margins", financed through the CNPq Research Productivity Scholarship - National Council for Scientific and Technological Development. Rio de Janeiro, under the strong influence of French culture, still breathed the air of a transition in which literature, theater and the growing interest in reading set the tone and decided the cultural direction of an emerging nation. In addition, serials, periodicals, newspapers, in general, and, in this case, Foyer, recorded, with singularity, the scenes of a population, of plural habits, that seemed to stage in life what happened on stages, mixing therefore, the daily life with theatrical art.
\end{abstract}

Keywords: Modernity, Newspapers, Social Life, Theater

\section{Introduction}

The 19th century was marked by several changes in the world, starting with the introduction of the sign of modernity from a rationality in thinking and the capitalism consolidation, with the industry heyday, consumption and new social and economic practices that transformed the face of society, with resonances in the most diverse fields of social life, from politics, economics, to literature and the arts:

The Industrial Revolution, with the rapid industrial development, brought about profound changes in European societies, traditionally agrarian, one of the most important was the fast process of transformation in cities. On one hand, the city became a public space where the poor population that lived in it escaped the surveillance and control, so common in the rural world [1].

In the sphere of modernity, there were great ruptures, among them the rational thinking, the rupture between church and state and a social imaginary that had full belief in science as a solution to all problems, which was materialized in the discourse of progress. Throughout the 19th century, the discourse of progress reached its high point in the West, having been reformulated in a different context, marked by industrial modernization, scientific positivism and evolutionism. During this period, a search was made for a "scientific organization" of humanity, and for the scientific control of social phenomena, which was largely addressed by authors such as Fourier, with his model of society -, 'Falansterio'; by Saint-Simon, with his technocratic guidelines and by Auguste Comte, with his positivist philosophy [2].

In this sense, progress and civilization became interconnected terms in the context of the 19th century and the city stood out as an emblem of modernity, from the emergence of the urban phenomenon as a civilizing process [3]. Undoubtedly, the modern city has changed Western civilization direction, creating new forms of sociability, which resulted in the creation of the entertainment industry from the 
second half of the 19th century:

There was a battle going on in those decades for the right to bourgeois identity. Its stage was largely the forms that the new metropolis will bring to perfection: the squares, the streets and the shows. The riverside crowds on Sunday afternoons - all walking back and forth in identical clothes, all eager to be seen - were engaged in a grand redefinition of what was going on in the middle class [4]

In the midst of the modern city new configuration, which has come to represent the civilization locus as opposed to the countryside, the new sociability develops not only in ordinary citizens but also in literatures, in artists, and the periodicals exalt the modern urban world, whether them in Europe or in other parts of the world as was the case in Brazil. In this context, the periodical press has an important role in the formation of modern society, precisely because it conveys modernity discourses imported from France:

Until the end of the 19th century, France is for Spain and Latin America the privileged reference, whether in relation to the main equipment for printing newspapers (including "utensils" and boards prepared for engraving) or final products in French or in the language of the country, such as either translated or adapted [...] or even pirated, but also when ordering publications made abroad and then imported, the French reference material dominates [5].

In this sense, the periodicals functioned as a sounding board for secular culture and also as a space for the formation of the "City of letters", that is, a space for the literacy to act as "men of letters" on the pages of newspapers, which significantly contributed to the professionalization of the writer: "Economic, social, technological and demographic changes allowed the proliferation of newspapers at the turn of the century, creating hundreds of jobs. And forming an audience for national literature" [5In Rio de Janeiro, several journals for the most diverse audiences proliferated, among them Foyer edited by Frederico de Souza and B.de Gouvêa and which constituted a periodical dealing specifically with theater matters. However, currently, it is only possible to find just one number of this newspaper, available in Hemeroteca National Library, raising two hypotheses of what may have happened: only a single copy of this newspaper was collected or, probably, it did not proceed, having been closed right after its first edition. Anyway, what we want to highlight in this work is the existence of the most varied journals, one of them with the title of Foyer, which already indicates the subject of its specialty and uses a word that is very popular in the late 19th century.

\section{In the Foyer of Theaters}

Foyer is the journal's title which circulated in Rio de Janeiro in 1891 . Without necessarily representing a digression, it is worth mentioning that the word Foyer etymologically has its origins in foueir; foujer, from Provencal; Spanish foguero and Latin; focus and meant the fireplace, that is, the space where people gathered around the fire to warm up and listen to stories [6]. (Dictionannaire LeRobert; Dictionnaire Littré. www.dictionnaire.lerobert.com/definition/foyer; www.littre.org/definition/foyer). In the Encyclopedia or in the Reasonable Dictionary of Sciences, Arts and Crafts, D'Alembert understands the foyer as a term for the theater, the room where the show is expected to start or spectators gather during their break. Both the etymological origin and the 18th century concept of encyclopedists point out that the Foyer is a space for sociability in the opera house or theater.

In theatrical architecture, according to Evelyn Furquim Werneck Lima, the foyer is part of the theater's constitution and 'it is located, on the same level as the cabins 'line', becoming a 'second show room', which denotes the ability to aggregate and become a showcase for theatergoers" [7]. The foyer as a space for sociability is, according to Benjamin, one of the places where the booklets of the modern city go in searching for raw material for their writing:

In this genre, issues of insignificant appearance, in pocket format, called 'physiologies', occupied a privileged place. They dealt with the description of the types found by those who visit the fair. From the street vendor on the boulevard to the elegant one in the opera foyer, there was no figure in Parisian life that the 'physiologist' had not portrayed. [8]

And if the foyer is, par excellence, a space for circulation and exhibition of people in the theater, the name of the periodical summarizes its predominant subject - the theater -, in addition to expressing the circulation space for the stage lovers, which characterizes the formation of new sociability from the development of the entertainment industry at the end of the 19th century. In fact, in this period there was an appreciation of sociability that is present in the European civilizing and bourgeois imaginary that, in turn, generated in the lifestyles, contrary to the rural ones. Frequency to the theater became imperative, replacing the space that exercised the trip to the church, for example.

The new values were becoming emblems of a new aristocracy - the bourgeois and the civilizing and modernizing discourses of the 19th century, intended to reach all social and cultural structures, including work, time, leisure, should also reach the most distant from Europe, as was Brazil's case, which, in turn, sought to integrate itself with the modern Western Civilization:

In the distant cities of Europe that began to rise at the end of the last century, such as Buenos Aires, Mexico, São Paulo and Rio de Janeiro, the ideas of progress, civilization, modern and good taste were represented by Europe, especially Paris and London, cradles of modernity. [9]

The Foyer periodical was divided like other newspapers of the period, in different subjects, but its predominant focus was the theater, according to its editorial. The discourse expressed in the text denotes the enthusiasm for modernization and the entertainment industry, as transcribed below:

Foyer

Who doesn't want to know what's going on in the Theaters? The public, of all classes, sanctions with its presence the growing interest that currently holds everyone in the movement of the scene. From the elegant to the worker, both the assertion of high society and the provocative 
INSTANTANEA, everyone is curious to know what drama is being played, what magic will make the career, what piece falls, what centenary is celebrated that $<<$ first $>>$ is announced; and many comments left and entrances by artists from this one to that stage revealing in all this a predilection for this kind of civilizing distraction that in every advanced country is the concern of part of its inhabitants. If «Foyer» manages to account for all of our theatrical movement, also illustrating its front space with a photograph of actors and actresses and an outline of each one's life, appreciating their labors and dismay, all without intention, just as a stimulus to others on a larger scale, won't you be able to call benevolence and public protection on yourself?! $<<$ Amuser les gens qui aiment le Thêatre et leur plaire $>>$. It is the end that $<<$ Foyer $>>$ proposes. [10]

As it is observed, the so-called civilization has been pursued recurrently since the end of the 18th century, reaching its high point in the second half of the 19th century, both in the fields of culture, behavior and politics, as pointed out by Norbert Elias. The author observed that the use of the word in the mentioned period brought a meaning that embraced the civilizer as a good, cultured, urban and educated subject [11]. Within the development of entertainment, the theater, together with other cultural manifestations, also assumed the function of civilizing, as we could see in the editorial of a newspaper published in Rio de Janeiro, Capital of the Empire and a place far from the great European centers.

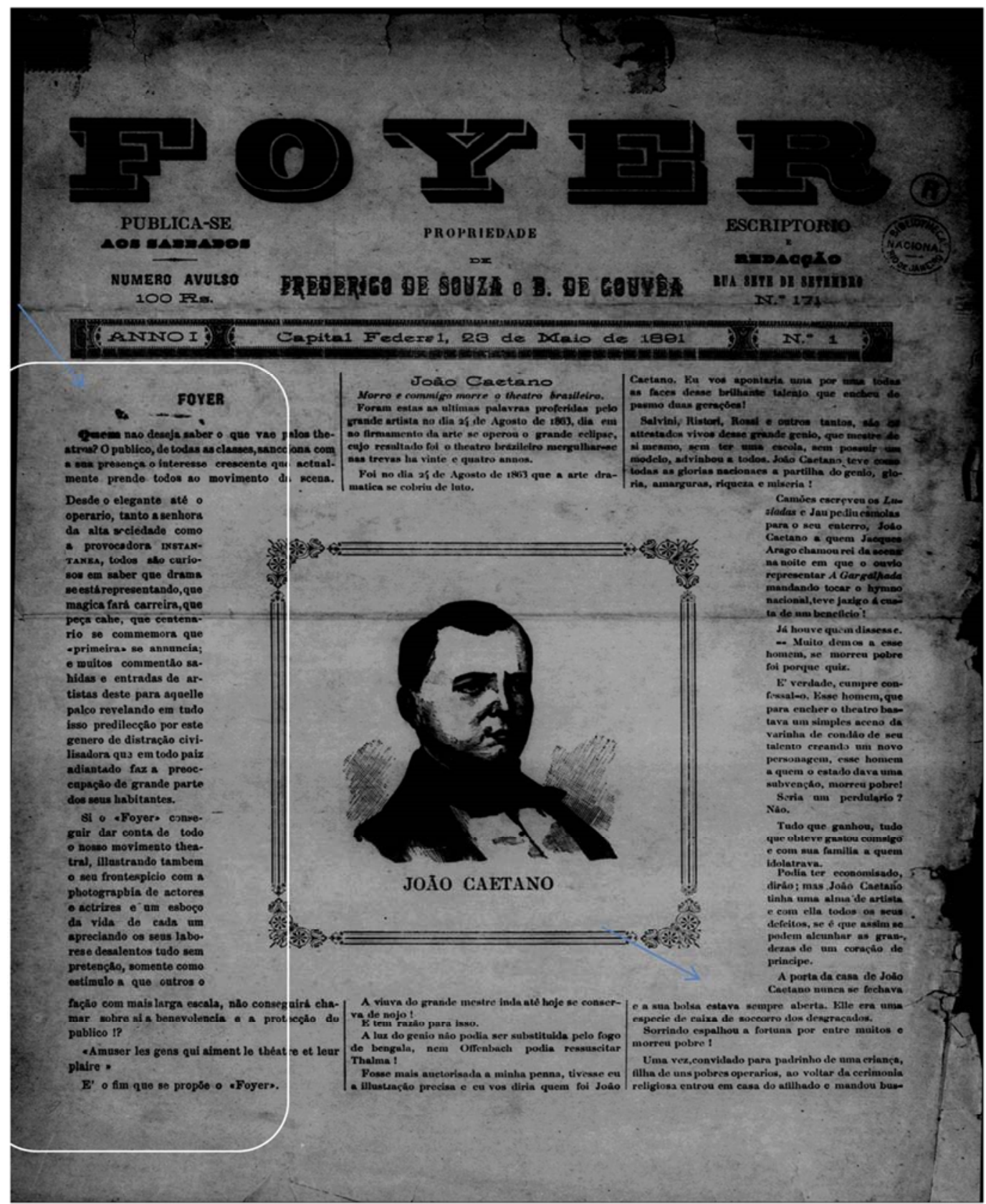

Figure 1. Foyer, n. 1, p. 1, year I. Code: TRB00722.0201; Label: 773247, 05/23/1891. Source: Digital Library of the National Library - Rio de Janeiro. (http://bndigital.bn.br/acervo-digital/Foyer/773247). 


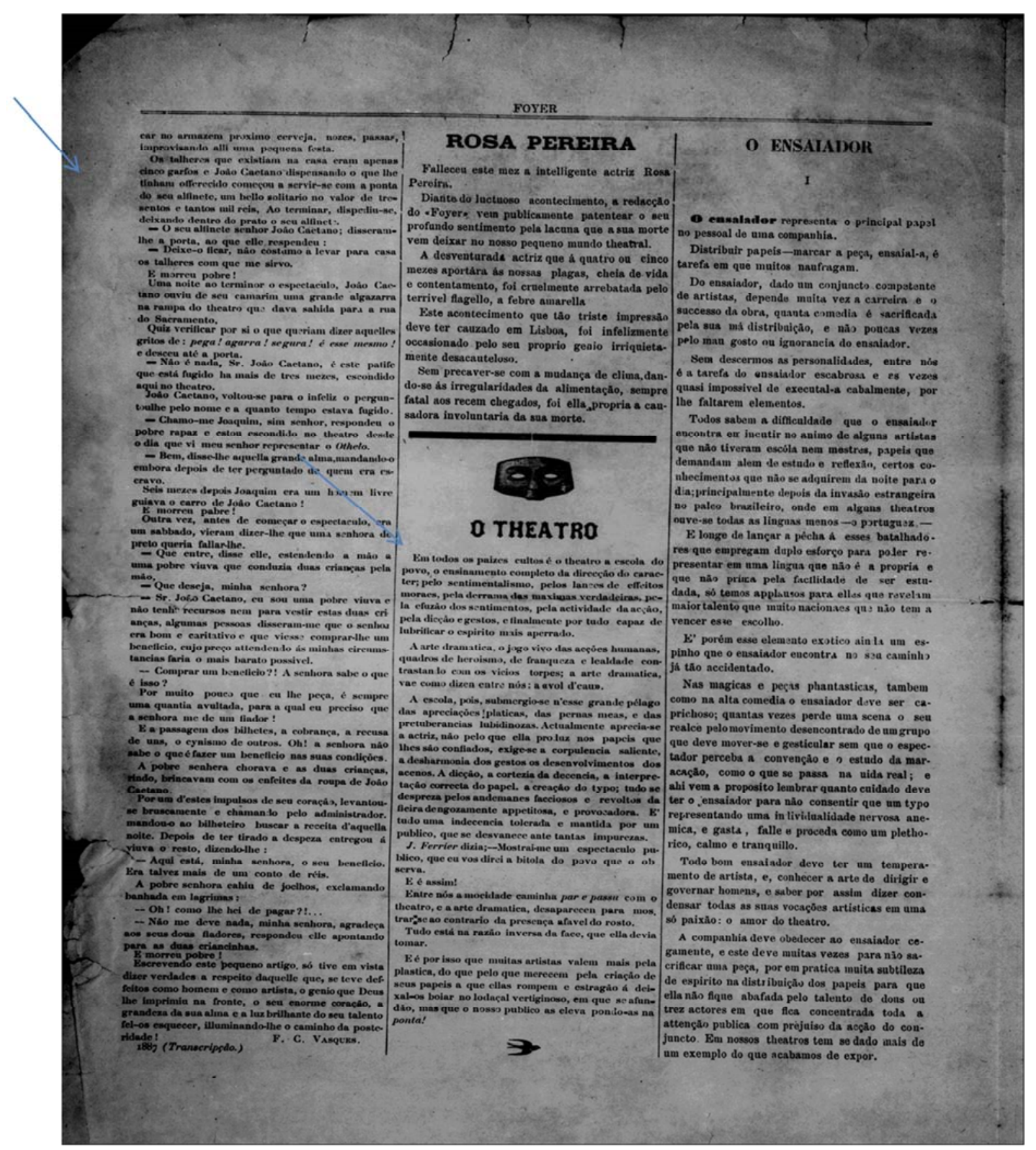

Figure 2. Foyer, n. 1, p. 1, year I. Code: TRB00722.0201; Label: 773247, 05/23/1891. Source: Digital Library of the National Library - Rio de Janeiro.

Still on the first page, actor and playwright Francisco Correa Vasques published a farewell chronicle about João Caetano, an important actor, born in the city of Rio de Janeiro, who started his career in an amateur way and managed to develop in a great way in the theater scenario to the point that his death was considered by the author to be an irreplaceable loss.

It was on the 24th of August 1863 that the dramatic art was covered with mourning. The widow of the great master is still disgusted today! And she is right for that. The genius light could not be replaced by cane fire, nor could Offenbach resurrect Thalma.

The author of the obituary, F. C. Vasques was an important chronicler of Gazeta da Tarde, having published a series entitled Scenas Comicas (October 18, 1883 until April 17, 1884). However, even if the moment called for a tone of mourning, the chronicler recalls picturesque and, at the same time, moving facts about João Caetano's trajectory:

(...)

The door to João Caetano's house never closed and his bag was always open. Elle was a kind of bailout for the bastards.

Smiling he spread his fortune among many and died poor!

Once, invited to be the godfather of a child, the daughter of some poor workers, when he returned from the religious ceremony, he went to his godson's house and ordered beer, nuts, raisins from the nearby warehouse, improvising every small party. 


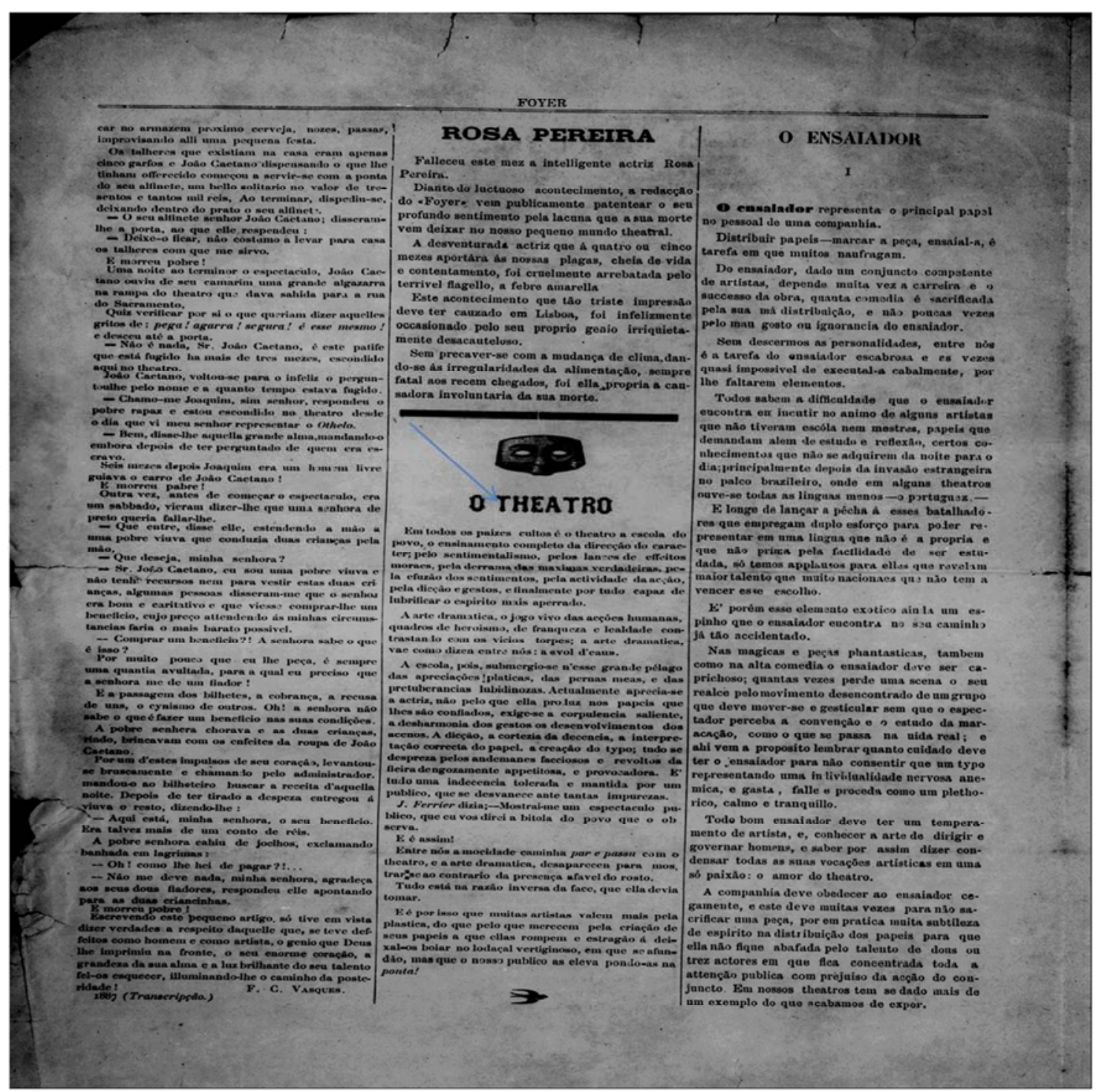

Figure 3. Foyer, n. 1, p. 2, year I. Code: TRB00722.0201; Label: 773247, 05/23/1891. Source: Digital Library of the National Library - Rio de Janeiro.

The cutlery that existed in the house were only five forks and João Caetano dispensing what they had offered began to help himself with the tip of his pin, a solitary bello worth three hundred and so many 'réis' bucks. When he finished, he said goodbye, leaving his pin.

- Your pin, Mr. João Caetano, said the door to which he replied:

- Let him stay, I don't usually take home the silverware I use.

And he died poor!

One night, at the end of the show, João Caetano heard from his dressing room, a great commotion on the ramp of the theater that led to Sacramento Street.

I wanted to check for myself what those cries of: Take it! Grab it! Hold on! That's him! And went down to the door.

- It's nothing, Mr. Joao Caetano, it's this rascal who has been on the run for more than three months, hiding here in the theater.

João Caetano turned to the unfortunate man, asked him by name and how much of it was missing.

- My name is Joaquim, yes sir, replied the poor boy and I have been hiding in the theater since the day I saw you represent Othelo.

- Well, that great soul told him, sending him away after having asked whose slave he was.

Six months later Joaquim was a free man, driving João Caetano's car!

And he died poor!

Again, before the show started, it was a Saturday, they came to tell him that a lady in black wanted to speak to him.

"Come in," he said, extending his hand to a poor widow who was leading two children by the hand.

- What do you want, my lady?

- Mr. João Caetano, I am a poor widow and I don't even have the resources to dress these two children, some people told me that you are good and charitable and that you come to buy a benefit. 


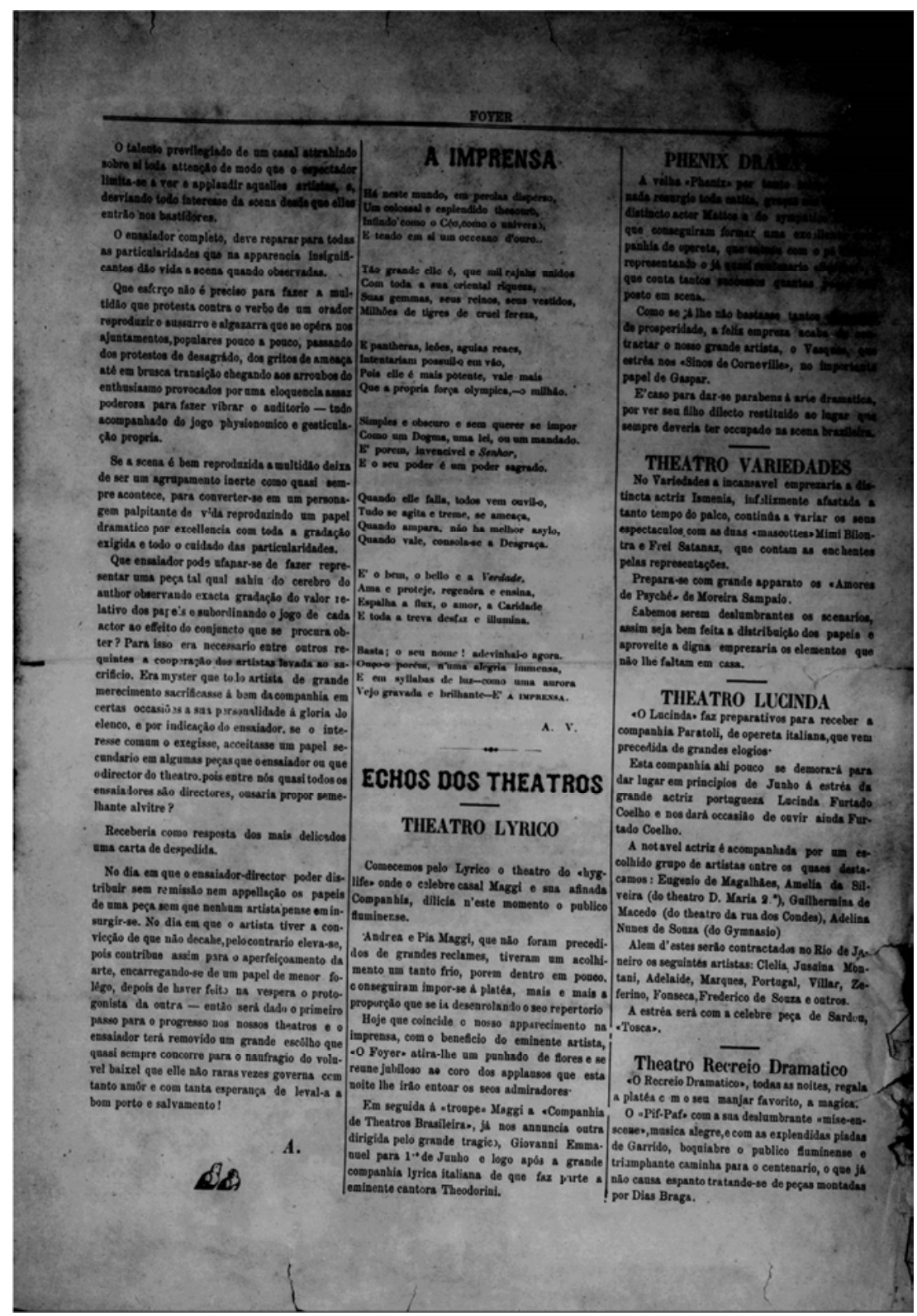

Figure 4. Foyer, n. 1, p. 3, year I. Code: TRB00722.0201; Label: 773247, 05/23/1891. Source: Digital Library of the National Library - Rio de Janeiro.

The poor lady was crying and the two children were playing with the ornaments of João Caetano's clothes.

For one of these impulses of the heart, he got up abruptly and, calling the administrator, sent him to the ticket office to get the recipe for that night. After cleaning, he handed the rest to the widow, saying:

- Here is, my lady, your benefit. It was perhaps more of a tale of 'réis' bucks

The poor lady fell to her knees, exclaiming in tears:

- Oh! How will I pay you?

"You owe me nothing, my lady, thank your two guarantors," he replied, pointing to the two little children.

And he died poor!

In writing this short article, I only intended to tell the truth about the one who, if he had defects as a man and as an artist, the genius that God imprinted on his forehead, his enormous heart, the greatness of his soul and the brilliant light of their talent will make them forget, illuminating the path of posterity!

F. C. Marques. 1891.

On the second page, the obituary records the Portuguese actress' death, Rosa Pereira, who had contracted yellow fever, a very common and fatal disease. At the time - in 1891, 4,312 deaths, caused by yellow fever, were recorded - and his departure is very regretted, leading to the idea that her presence was of great relevance in the theater. It is possible to raise an assumption that, although the actress was important to the theater, she did not compare herself to João Caetano due to the discrepancy in the size of her respective stories and the fact that he was on the front page. However, it is not known if her relevance in the theater was really inferior or if there is only this difference because she is a woman, taking into account the time and all its implications in the invisibility of female sex. 
The writer of the newspaper Foyer welcomes the theater in its civilizing function and as urban and mundane leisure. The theater was a space where people went not only to be seen, but it was also a place for romantic encounters. More than representing the civilization that one wanted to achieve, within a morality, going to the theater was characterized, above all, as a worldly pleasure.

\section{Theater}

In all cultured countries, the theater is the people's school, the complete teaching of the direction of the character, by sentimentality, by the moral effects, by the spilling of the true maxims, by the profusion of the feelings, by the activity of the action, by the diction and gestures and finally, for everything capable of lubricating the most hectic spirit.

In the last articles on page two, it is emphasized the importance of the emotions transmitted through the theater to the audience and how easily this can be applied in life as a whole, suggesting that the theater is the school of liberation from feelings. On the other hand, it is emphasized that it is not simply a play or actors that bring such commotion to the surface, it is necessary to have a good rehearser, who knows how to format the best way the work will be conducted and give life to the characters.

This point in the article is very important to break the stereotype that the theater constitutes only a script, with protagonists, extras and decorated speeches, but, rather, to reveal that there is a lot of work involved "behind the curtains" that should be valued. In fact, the mention that is made about cultured countries, which are inspired by theater, is precisely to emphasize that in Brazil, works and everything they represent should also be valued, not only subduing them as mere fictions.

On the following pages, the periodical carries several advertisements for plays and theatrical establishments in Rio de Janeiro, which shows its initial proposal, that is, bringing the theater closer to the population and disseminating it more, emphasizing its magnitude.

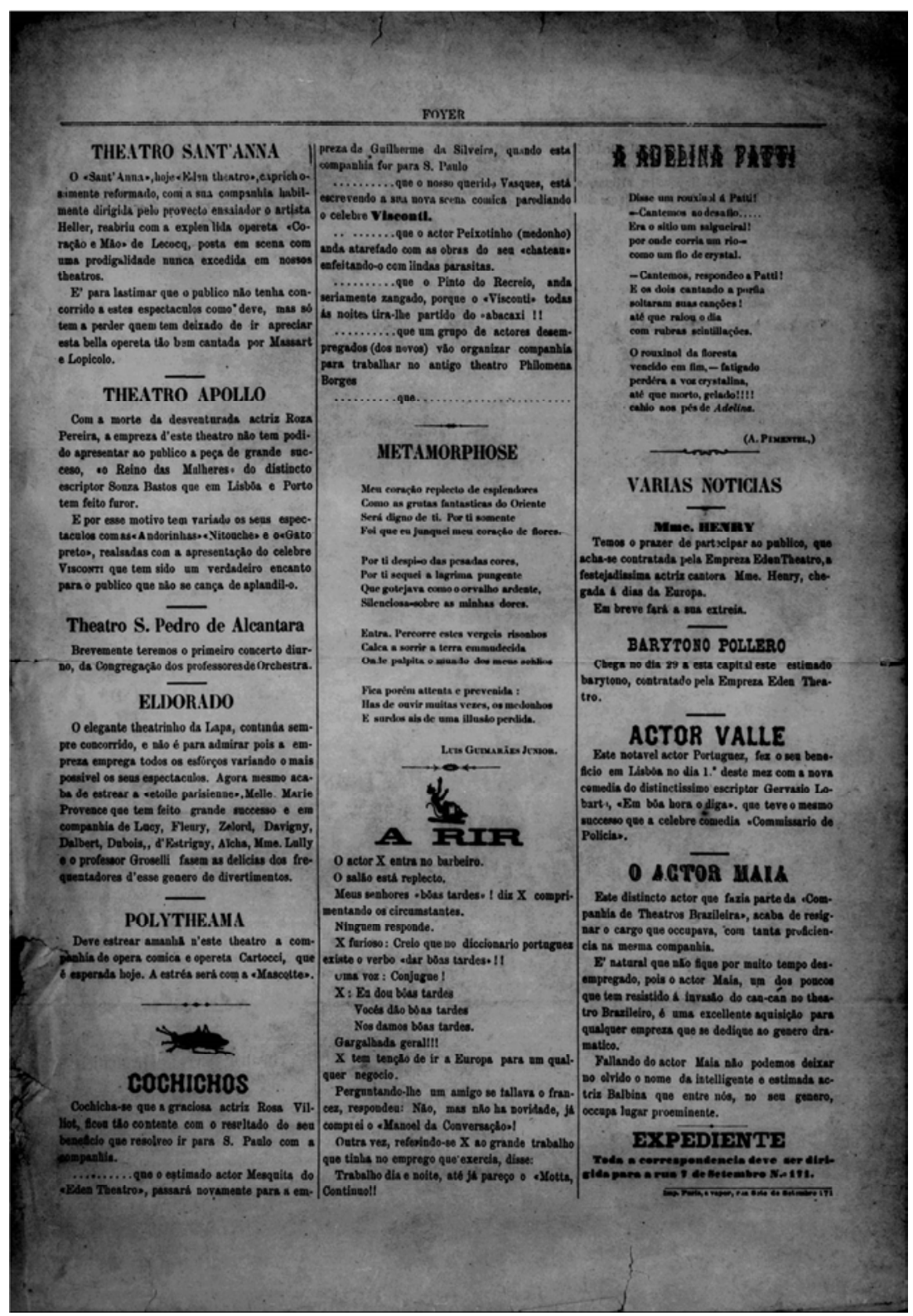

Figure 5. Foyer, n. 1, p. 4, year I. Code: TRB00722.0201; Label: 773247, 05/23/1891. Source: Digital Library of the National Library - Rio de Janeiro. 


\section{Final Considerations}

It is unclear why only one issue of the Foyer periodical is available. We speculate on two main hypotheses: the first would be that it ended up not becoming popular and, consequently, not obtaining a satisfactory adhesion from most people, and therefore his non-continuity. The other version would be that, over time, the other editions were lost, with only the first one being found.

However, the most important thing to note is that Foyer was one of many initiatives to promote theater in a country, which still did not have a long cultural tradition in theater and, through the press, was gradually building its nation as "imagined community" [12].

Receiving the new airs of Europe, as French culture became the major influencer in the field of arts, Brazil did not have its eyes only on the roots of colonization, which already showed a change in perspectives, be it in the political and economic angle, whether in the linguistic or literary aspect. In this sense, it is worth highlighting the relevance that the periodical Foyer, despite its brevity in the typographic trails, left its impressions, its marks and that, in the final analysis, not only registered the scenes of a rising culture, but also scored incisive, the embryonic life in Brazilian theater that, paradoxically, was already emerging as a public space with strong artistic appeal and performance, and possibly one of the effervescent channels for the dissemination of plural ideologies and ideas, typical of artistic environments.

It should also be noted that Brazilian culture, at that time, was strongly influenced by newspapers, since books in Brazil were a rare object and serials, either occupied this gap or performed that function; fact historically consolidated through national literature at the time of Romanticism. Furthermore, it is important to point out that the dramatic genre had definitely invaded the theater, becoming popular and feeding back textual and literary chains.

Thus, as a documentary source or bridge that brought together important links in the nascent cultural scene, Foyer fulfilled its role as a propelling element of literary art in Brazil, so, constituting a space in which intellectuals, artists and part of the national rising intelligentsia coexisted.

\section{References}

[1] Martinho, 2000, MARTINHO, Francisco Carlos Palomanes "Resistências ao Capitalismo: Plebeus, Operários e Mulheres". In REIS FILHO, Daniel A. et. al. O Século XX. Rio de Janeiro: Civilização Brasileira, 2000. Volume 1. p. 190-200.

[2] Matos, O. A Escola de Frankfurt. Sombras e luzes do Iluminismo. São Paulo: Moderna, 1993.

[3] Nascimento, L. (2018). "A cidade como palco e seus desígnios na literatura", Policromias, Revista de Estudos do Discurso, Imagem e Som, 3, 1, 24-31. Available on: https://revistas.ufrj.br/index.php/policromias/article/view/1534 5. Accessed at: Apr. 4, 2019.

[4] Clark, T. J. A pintura da vida moderna. Paris na arte de Manet e de seus seguidores. Trad. José Geraldo Couto. São Paulo: Companhia das Letras, 2004.

[5] Botrel, J.-F. "Impressos sem fronteiras no século XIX: França/Espanha/América Latina" in Transferências culturais: o exemplo da imprensa na França e no Brasil, Guimarães, V., Ed. Campinas: Mercado das Letras; São Paulo: Edusp, 2012, pp. 55-72.

[6] Denis Diderot, J. le R. d'A., Pimenta, P. P.; Souza, M. das G. de, Eds.. Enciclopédia, ou dicionário razoado das ciências, das artes e dos ofícios. São Paulo: Ed da UNESP. 2015. (Dictionannaire LeRobert; Dictionnaire Littré. www.dictionnaire.lerobert.com/definition/foyer; www.littre.org/definition/foyer).

[7] Lima, E. F. W. "Entre o teatro e a cidade", in Espaço e teatro: do edifício teatral à cidade como palco, Lima, E. F. W. Ed. Rio de Janeiro: 7 Letras, 2008, pp. 7-10.

[8] Benjamin, W. Charles Baudelaire, um lírico no auge do capitalismo. Trad. José Carlos Martins Barbosa; Hemerson Alves Baptista. São Paulo: Ed. Brasiliense, 1989.

[9] Moraes, J. G. V. de. Cidade e cultura urbana na Primeira República. São Paulo: Atual, 1994.

[10] Foyer, ano I, n. 001, Rio de Janeiro, 1891, p. 1. Código: TRB00722.0201; rótulo 773247, 4p. Acervo Fundação Biblioteca Nacional - Rio de Janeiro-RJ- Brasil.

[11] Elias, N. O processo civilizador: uma história dos costumes, v I. Trad. Ruy Jungmann. Rio de Janeiro: Jorge Zahar Ed., 1994.

[12] Anderson, B. Comunidades imaginadas: reflexões sobre a origem e a difusão do nacionalismo. Trad. Denise Botmann. São Paulo: Companhia das Letras, 2008. 